Dossiê

Literatura e Arquivos 



\title{
Da literatura industrial ${ }^{1}$
}

\author{
Sainte-Beuve ${ }^{2}$
}

De longe, a literatura de uma época apresenta-se em seu conjunto como uma coisa simples; de perto ela se desenvolve sucessivamente com todo tipo de diversidades e diferenças. Ela está em marcha; nada se completou ainda. Ela tem seus progressos, seus fracassos, seus momentos de hesitação ou de arrebatamento. É oportuno notá-los no momento, assinalar suas falsas rotas, suas propensões ruinosas; isso nem sempre é em vão. De resto, fazemos parte do grosso da caravana, fatalmente nos interessamos pelo assunto, fala-se dele à nossa volta com toda a liberdade: às vezes é bom escrever como se fala e como se pensa.

É um fato a aflição e o desastre do comércio livreiro na França desde alguns anos; desde alguns meses o mal piorou ainda mais: pode-se ver nisso, sobretudo, um grave sintoma. A coisa literária (compreendendo sob este nome, particularmente, o conjunto das produções da imaginação e da arte) parece cada vez mais comprometida, e por sua própria culpa. Se contarmos as exceções aqui e ali, elas vão como que se distanciando, se desvanecendo em um vasto naufrágio: rari nantes. ${ }^{3}$ A fisionomia do conjunto domina, o nível do mal progride e cresce. Só se encontram engenhos cultivados que se preocupam com isso como por um arroubo. Parece que não lidamos com um acidente lamentável, com uma simples queda de granizo de uma estação menos feliz, mas sim com um resultado geral que tem causas profundas e que deve antes aumentar.

Quando, há apenas dez anos, uma brusca revolução veio romper a série de estudos e de ideias que estavam em pleno desenvolvimento, seguiu-se uma primeira e longa anarquia; nessa confusão inevitável, pelo menos se produziram novos talentos; os antigos não haviam perecido; podia-se esperar em uma ordem renascente um desenvolvimento literário satisfatório ao coração e glorioso. Mas eis que em literatura, como em política, à medida que cessaram as causas exteriores de perturbação, os sintomas interiores e de desorganização profunda se deixaram ver melhor. Eu me limitarei aqui à literatura.

Sob a Restauração, sem dúvida, escrevia-se muito, e de todas as maneiras. Ao lado de alguns verdadeiros monumentos, produzia-se uma multidão de obras mais ou menos secundárias, sobretudo políticas e históricas. A imaginação não havia ainda despertado, a não ser entre os talentos de elite. A essa quantidade de escritos de circunstância e de combate, uma ideia moral, uma aparência de patriotismo, uma bandeira dava uma espécie de nobreza e recobria, aos olhos do público, aos olhos dos próprios autores e compiladores, a motivação mais secreta. Desde a Restauração, e no momento em que ela ruiu, essas ideias morais e políticas, em sua maioria, se abateram subitamente; a bandeira deixou de tremular sobre todo um carregamento de obras que ela honrava, encobrindo a mercadoria, como se diz. A grande massa da literatura, todo esse capital livre e flutuante que se designa um pouco vagamente sob esse nome, não mais sentiu no seu interior e não mais acusou no seu exterior senão as suas motivações reais, a saber, uma competição desenfreada dos amores próprios e uma necessidade imperiosa de viver: a literatura industrial cada vez mais se desmascarou. 
Para não se assustar com a palavra, para melhor combater a coisa, primeiro não se deve exagerar. Em todos os tempos existiu a literatura industrial. Sobretudo desde que se imprime, escreveu-se para viver, e a maior parte dos livros impressos é devida sem dúvida a esse motivo tão respeitável. Combinada com as paixões e as crenças de cada um, com o talento natural, a pobreza engendrou sua parte, mesmo das obras mais nobres, e daquelas que têm o ar mais desinteressado. Paupertas impulit audax ${ }^{4}$, diz-nos Horácio, e Le Sage escrevia Gil Blas para o livreiro. Em geral, no entanto, sobretudo na França, ao longo dos séculos XVII e XVIII, ideias de liberalidade e desinteresse estavam, com razão, ligadas às belas obras.

Eu sei que um nobre engenho pode, sem vergonha e sem crime, tirar de seu trabalho um tributo legítimo,

dizia Boileau, em favor de Racine, como uma espécie de concessão. ${ }^{5}$ O próprio Boileau dava seus versos de presente a Barbin e não os vendia. Em todos esses monumentos majestosos e diversamente contínuos, dos Bossuets, dos Fenelons, dos La Bruyère, naqueles de Montesquieu e de Buffon, não se percebe uma porta que leve aos fundos da livraria. Voltaire enriquecia antes pelas especulações estrangeiras que pelos seus livros, que, no entanto, ele não negligenciava. Diderot, necessitado, dava seu trabalho mais facilmente que o vendia. Bernardin de Saint-Pierre foi um dos primeiros a oferecer o triste espetáculo de um talento elevado, ideal e poético, em chicana com os livreiros. Beaumarchais, o grande corruptor, começou a especular de modo genial sobre as edições e a combinar $\mathrm{Law}^{6}$ com o escritor. Mas, em geral, a dignidade das letras subsistia, recobrindo toda essa parte material secundária e mantendo o preconceito honorável no qual hoje somos sacudidos tão violentamente. Sob o Império, relativamente, escrevia-se pouco; sob a Restauração, escrevendo-se muito, guardaram-se, eu disse, nobres aparências. Aconteceu então que, deixando os hábitos generosos ou especiosos da restauração, e com nossa soma de preconceitos um pouco delicados nessa matéria, hoje, que a literatura puramente industrial se alardeia cruamente, a coisa nos parece muito mais nova do que é de fato: é verdade que as pretensões manifestas e a ameaça de invasão nunca haviam atingido um nível tão alto.

O que caracteriza essa literatura neste momento e faz dela um fenômeno totalmente próprio do nosso tempo é a ingenuidade e muitas vezes a audácia de sua pretensão; de estar necessitada e ultrapassar todos os limites do necessário com suas demandas; de se misturar a uma paixão desenfreada pela glória, ou antes, pela celebridade; de se amalgamar intimamente com o orgulho literário; de se oferecer como medida e de tomar a si mesma como medida na emulação de suas exigências acumuladas; é reencontrá-la onde menos suporíamos ou desculparíamos, nos ramos mais floridos da imaginação, naqueles que pareceriam pertencer às partes mais delicadas e mais finas do talento.

Cada época tem sua loucura e seu ridículo; em literatura nós já assistimos (e já demos muito apoio, talvez) a muitas manias; o demônio da elegia, do desespero, teve seu tempo; a arte pura teve seu culto, sua mística; mas eis que a máscara muda; a indústria penetra o sonho e o faz à sua imagem, fazendo-se fantástica como ele; o demônio da propriedade literária sobe às cabeças e parece constituir em alguns uma verdadeira doença 
pindárica, uma dança de São Guido curiosa de se descrever. ${ }^{7}$ Cada um, exagerando sua importância, põe-se a avaliar o próprio gênio em somas redondas; o jorro de cada orgulho cai como chuva de ouro. Isso chega facilmente aos milhões e não se enrubesce de expô-los e de mendigá-los. Em mais de um caso ilustre, o discurso não sai mais disso: é um grito de miséria em estilo de alta finança e com acompanhamento de espécie sonante. Marot, em algumas graciosas décimas, estendendo a mão ao Rei para ter cem escudos punha nisso menos afetação e mais graça. ${ }^{8}$

No entanto, sobre este ponto, como sobre quase todos os outros que dizem respeito à literatura, não se levanta nenhuma censura, nenhum riso alto e franco: não se faz mais o controle externo. A literatura industrial chegou a suprimir a crítica e ocupar o seu lugar quase sem contradição e como se ela existisse sozinha. Sem dúvida, para quem considera as produções da época de uma perspectiva completa, há outras literaturas coexistentes e que não deixam de realizar sérios e honoráveis trabalhos: por exemplo, a literatura que se pode chamar da Academia das Inscrições e que permanece fiel à sua missão de crítica e de pesquisa, à qual leva um aumento de atividade, introduzindo-lhe alguma juventude; há ainda a literatura que se pode chamar da Universidade, confinando com a outra, e que pelo ensino, por meio de teses que se tornam obras, desde muito saiu da rotina sem perder a tradição. Mas com toda a estima que tais trabalhos inspiram, é preciso dizer que não se encontra aí toda a glória literária de uma nação; até mesmo alguma vida livre e ousada sempre buscou aventura fora desses circuitos: é no grande campo externo que a imaginação tem todas as chances de se manifestar. Ora, este campo livre, que formou até aqui a principal honra da França, que é feito dele? Sua condição de ser comum e aberto a todos, sem dúvida, deixou-o, a cada época, exposto a todos os acasos das inteligências. Aí passaram as diferentes formas de mau gosto, as modas variegadas, as escolas ruidosas; aí fizeram um dilúvio as falsas aparências. Este campo, em uma palavra, foi em todos os tempos infestado por bandos; mas jamais ele chegou a ser invadido, explorado, reclamado a título de justa posse por um bando tão numeroso, tão díspar e quase organizado como vemos hoje, e com esta única divisa escrita na bandeira: Viver escrevendo. Por desdém ou intimidação, nós nos calamos e isso se propaga; espíritos sérios e que honram a época, fechados em suas vocações especiais, guardam silêncio sobre os excessos que não saberiam como qualificar. No entanto, grandes e elevados talentos, aborrecidos ou cegados, cedem à torrente e impelem, imitam e encorajam os desregramentos dos quais sempre acreditam poder se livrar sem desonra. Algumas penas sábias protestam aqui e ali, em surdina; mas em parte alguma se levanta um dique. A conivência extingue todo grito de alarme. Sobre certas questões atuais e sensíveis, estamos reduzidos (quem diria?) a ter por sentinela audaz apenas a inteligência e o capricho de M. Janin ${ }^{9}$, que diz essa manhã, com um sonoro bom senso, o que todo mundo pensa. Jamais se sentiu melhor, no seio da literatura usual e da crítica ativa, a falta de tantos escritores de engenho, instruídos, conscienciosos, que haviam tido um tão belo papel nos últimos anos da Restauração, e que, no momento da revolução de julho, passando bruscamente à política, de fato abandonaram a literatura. Por mais altos serviços que possam pensar ter prestado à sua causa os antigos escritores que se tornaram deputados, conselheiros de estado e ministros, estou persuadido que, refletindo sobre isso, pelo menos alguns dentre eles imaginam, em um arrependimento tácito, os outros 
serviços crescentes que teriam podido prestar, com não menos brilho, a uma causa que é também a da sociedade: bastava-lhes ousar permanecer sob sua primeira forma, manter sua tribuna filosófica e literária, continuando a praticar, por algumas de suas penas, sua missão de crítica elevada e vigilante: nos tempos de calma, se reencontraria a autoridade. Sua brusca retirada deixou uma lacuna e, por esse total deslocamento de forças, pode-se afirmar que houve solução de continuidade, mais em literatura do que em política, entre os regimes de antes e depois de julho. Os talentos novos e as jovens esperanças não mais encontraram um grupo já formado e experimentado ao qual pudessem se unir; cada um buscou fortuna e traçou seu caminho ao acaso; vários se desviaram para sistemas totalmente excêntricos, mas os únicos que ofereciam algum corpo de doutrina, ainda que pouco imponente. Muitos, permanecendo no meio comum, expostos a esta atmosfera colérica e inflamada, sobre este solo pouco seguro, exposto a todas as causas de excitação e de corrupção, foram mais ou menos estragados, e não souberam ser mais nada além disso. Daí, uma literatura com uma fisionomia, até o presente, singular em seu conjunto, ativa, efervescente, ambiciosa, ousando tudo, trazendo as paixões mais refinadas da civilização com a sem-cerimônia desenfreada do estado de natureza; perdendo uma primeira aposta de generosidade e de talento em turbilhões de egoísmo e cupidez que se alargam orgulhosamente; e não tendo podido encontrar até aqui, no meio de suas pretensões, de suas animosidades intestinas, uma aparência de unidade, senão em ligas momentâneas de interesses e amores próprios, em puras coalizões que violam a primeira palavra de toda moral: harmonia.

Eu não exagero. Na província, mesmo em Paris, se ambas não estão mais ou menos misturadas, ignora-se o que seja no fundo a imprensa, este ruidoso ponto de encontro, este poeirento bulevar da literatura do dia, mas que tem, em cada alameda, suas passagens secretas. Falando da imprensa, eu sei quais exceções convém fazer; eu poderia notá-las, sobretudo politicamente; mas literariamente há muito pouco a reconhecer. A menor importância que se dá provavelmente a um ramo reputado acessório fez que este aspecto ficasse ao deus-dará. Disso resultou, na maior parte dos jornais, mesmo em alguns daqueles que passariam de bom grado por puritanos, um conjunto de abusos e uma organização puramente mercantil que fomenta a praga literária que se avizinha e que dela depende.

Uma primeira restrição, todavia, deve ser feita à condenação. É preciso se resignar aos hábitos novos, à invasão da democracia literária como ao advento de todas as outras democracias. Pouco importa que isso pareça mais gritante em literatura. Escrever e fazer imprimir serão cada vez menos um traço distintivo. Com nossos costumes eleitorais, industriais, todo mundo, pelo menos uma vez na vida, terá tido sua página, seu discurso, seu prospecto, seu toast, será autor. Daí a fazer um folhetim, não há mais que um passo. "Por que não eu?" - cada um dirá a si mesmo. Estímulos respeitáveis se intrometem aí. Porque tem uma família, porque casou por amor, até a mulher escreverá sob um pseudônimo. O que há de mais respeitável, de mais digno de interesse que o trabalho assíduo (ainda que um pouco apressado e negligente) de um escritor pobre, vivendo disso e sustentando os seus? Essas situações são frequentes: haveria escrúpulo em depreciá-las. 
Além do mais, quem, em nossos dias, pode, então, dizer que não escreve um pouco para viver (pro victu), desde os mais ilustres? Esse motivo acompanha até a mais legítima glória. Pascal, Montaigne, falando dos filósofos que escrevem contra a glória, os mostram em contradição consigo mesmos e desejando-a. E eu, que escrevo isso, acrescenta Pascal... E eu mesmo, que escrevo isso, devemos nos dizer quando escrevemos sobre aqueles que escrevem um pouco para viver.

Mas feitas essas advertências, tomadas essas precauções, e tirando proveito dessa audácia que se apoia na própria necessidade, e dessa inspiração áspera e livre de uma vida cada vez mais desembaraçada, estamos na posição e no direito de dizer a verdade como a entendemos sobre um conjunto cuja impressão não deixa dúvida, cujo resultado revolta e grita cada vez mais. O estado atual da imprensa cotidiana, no que concerne à literatura, é, para dizer sem rodeios, desastroso. Não se contrapondo nenhuma ideia moral, aconteceu que uma série de circunstâncias materiais gradualmente alterou o pensamento e desnaturou a sua expressão. Por exemplo, M. de Martignac ${ }^{10}$ legou, sem dúvida, um germe de morte aos jornais por sua lei de julho de 1828, lei mais liberal, mas que, tornando as publicações quotidianas ou periódicas mais acessíveis a todos, sob certos aspectos, onerou-as de certas condições pecuniárias como contrapeso, e que, aliviando-as no que respeita à polícia e à política, fez crescer em seu seio o peso industrial. "Que faremos para socorrer às novas despesas?" - diziam os jornais. "Ora, fareis anúncios", responderam-lhes. Os jornais cresceram; o anúncio nasceu, modesto ainda durante algum tempo; mas essa foi a infância de Gargantua, e logo ele passou aos prodígios. As consequências dos anúncios foram rápidas e infinitas. É inútil querer separar no jornal o que permanecia consciencioso e livre do que se tornava público e venal: o limite do filete $^{11}$ foi logo transposto. O reclame ${ }^{12}$ serviu de ponte. Como condenar a dois dedos de distância, qualificar detestável e funesto o que se proclamava e se apregoava dois dedos abaixo como a maravilha da época? A atração das maiúsculas crescentes do anúncio prevaleceu: foi uma montanha de ímã que fez mentir a bússola. A fim de ter em caixa o lucro do anúncio, tiveram complacência com os livros anunciados; aí a crítica perdeu seu crédito. Que importa? $\mathrm{O}$ anúncio não era a parte mais produtiva e mais líquida da empresa? Apareceram jornais fundados unicamente sobre o produto presumido do anúncio: então, sobretudo a complacência foi obrigatória; toda independência e toda reserva cessaram.

Esse infeliz anúncio não teve uma influência menos fatal sobre o comércio livreiro; no que lhe diz respeito, ele bem contribuiu para matá-lo. Como? $\mathrm{O}$ anúncio constitui, após a impressão, um acréscimo de despesa que é preciso antecipar sobre a primeira venda, antes de esperar qualquer lucro; mil francos de anúncios para uma obra nova; além disso, a partir de então, os livreiros exigiram impiedosamente dos autores dois volumes em vez de um, e volumes in- $8^{\circ}$ em vez de um formato menor; pois isso não custa mais para anunciar, e, permanecendo a mesma a despesa dos anúncios, a venda é pelo menos duplicada e recupera o custo. De um efeito a outro, eu não concluiria tão cedo sobre o anúncio, que demandaria toda uma história: Swift, com sua tinta amarga, poderia traçá-la.

A situação dos jornais piorou notavelmente depois da introdução da chamada imprensa de quarenta francos. ${ }^{13}$ Eu me limito a julgar apenas sua consequência moral. $\mathrm{O}$ personagem, demasiado célebre e de uma capacidade tão incontestável quanto mal dirigida, 
que teve essa ideia ousada, pretendia matar o que se chamava o monopólio de alguns grandes jornais; mas ele não fez mais do que colocar todo mundo e a si próprio em condições mais ou menos ilusórias, nas quais se torna cada vez mais difícil, para falar apenas de literatura, sair das dificuldades com verdade, com franqueza. Os jornais, por essa baixa de preço, por esse aumento de formato, tornaram-se cada vez mais tributários do anúncio: ele perdeu seu resto de pudor, se é que o tinha. Agora, quando se lê em um grande jornal o elogio de um livro, e quando o nome do crítico não oferece uma garantia absoluta, nunca se está muito seguro de que o livreiro ou mesmo o autor (se por um acaso extraordinário o autor é rico) não estão um pouco envolvidos. É lamentável que, na origem dessa espécie de invasão da chamada imprensa de quarenta francos, as consequências morais e literárias não tenham sido apresentadas com vigor e clareza por alguma das penas que então gozavam de crédito. Uma voz, no entanto, a de Carrel ${ }^{14}$, começara a se levantar quando se calou. Os outros jornais sem dúvida tinham muitos interesses envolvidos nessa questão e o Sois ourives ${ }^{15}$ diminuiu a autoridade de sua resistência. Apesar dessa posição desfavorável, certos fatos poderiam sobressair com evidência e certeza. Eu creio, por exemplo, que foi um erro do Journal des Débats ${ }^{16}$, que, apesar de tudo, se manteve à frente da literatura periódica, obedecer nessa crise ao seu sistema de prudência, e não protestar mais alto. Mas como, então, no Governo, homens de Estado sérios e virtuosos puderam apoiar irrefletidamente, e por razões puramente momentâneas, operações que jamais apresentaram nenhuma chance de sucesso legítimo e que visivelmente levavam a uma corrupção imediata? O que é certo (e sempre restringindo nosso ponto de vista) é que a moralidade literária da imprensa em geral desceu um degrau desde então. Se pintássemos esses costumes em todos os seus detalhes, não nos acreditariam. M. de Balzac reuniu, ultimamente, muitas dessas vilanias em um romance que tem por título Un grand homme de province ${ }^{17}$, mas envolvendo-as no seu fantástico usual: como último traço que ele omitiu, todas essas revelações curiosas não o indispuseram com as pessoas em questão, desde que seus interesses tornaram-se comuns.

No teatro, encontrar-se-iam as mesmas pragas; os costumes abertamente industriais têm aí um lugar ainda mais evidente. Sempre foi assim: mas, em uma história do teatro dos últimos dez anos, acompanharíamos a consequência crescente e desordenada desse mau regime literário. A exigência dos autores em voga aumenta e muitas vezes se assemelha bastante à voracidade. Para mantê-los, há, por exemplo, o incentivo dos prêmios: tão logo uma peça de um deles é lida e recebida, uma soma é dada, cinco mil francos, eu creio, se a peça tem cinco atos. Quando a peça tem sucesso, quando os contratos se cumprem com alguma fidelidade, tudo vai bem, mas em geral não é assim. Mas às vezes os teatros se saem melhor que o resto. Sua praga real sempre esteve na raridade de boas peças e de bons assuntos, bons atores. Uma única boa fortuna nesse gênero recupera muitas perdas. Passemos.

É na literatura impressa, particularmente na de imaginação, nos livros antes suscetíveis à moda e, pouco a pouco, em quase todas as obras novas, que o mal, sob a forma que nós denunciamos, atacou profundamente. Sobretudo há dois anos não se vende mais: o comércio livreiro morre. Tanto se abusou do público, tanto se pôs papel em branco em volumes inflados e caros, tanto se reimprimiu o velho por novo, tanto se 
louvou de todas as maneiras o insípido e o chato, que o público tornou-se rigorosamente um cadáver. Os gabinetes de leitura pouco compram. Ultimamente vimos um autor reclamar bem alto contra o uso de alguns desses gabinetes, que, para não se arruinarem em compras duplicadas, recortam dos jornais e fazem encadernar os romances que aparecem em folhetins: o autor denunciava com indignação essa medida econômica: por sorte ele não denunciou ao procurador do rei. Mas também o que esperar de um livro quando ele não faz mais do que ajuntar páginas escritas para encher o máximo de colunas com o mínimo de ideias? Os jornais crescendo, os folhetins se estendendo indefinidamente, a elasticidade das frases teve que se esticar, e redobraram-se as palavras vãs, as descrições ociosas, os epítetos redundantes: o estilo se estiron em todos seus fios como os tecidos muito esticados. Há autores que só escrevem seus romances de folhetins em diálogos, porque a cada frase, e às vezes a cada palavra, há um branco e ganha-se uma linha. Ora, sabeis o que é uma linha? Uma linha a menos em ideia, quando acontece com frequência, é uma notável economia de cérebro; uma linha a mais na conta é às vezes uma soma bem razoável. Há certo escritor de renome que exige (quando ele condescende com os jornais) que lhe paguem dois francos por linha ou por verso, e que talvez ainda acrescente que isso não é tanto quanto se paga a lord Byron. Eis o que é saber ao certo a dignidade e o preço do pensamento. Ele encontra empresários charlatões que consentem nesses excessos de pretensão para ter ao menos um artigo e se enfeitar com um nome: isso se recupera sobre o acionista. Homens ignorantes das letras, invadindo o comércio livreiro e sonhando com ganhos quiméricos, fizeram calar os cálculos sensatos e favoreceram os sonhos cúpidos. Assim, cada um foi diretamente ao seu egoísmo, cortando a árvore pela raiz. Cada um, aí passando, arruinou o terreno sob seus passos: que importa os que vierem depois? Depois de nós o dilúvio! O escritor, tendo imposto ao seu cérebro compromissos onerosos, teve decepções, bom ano e mau ano, como se diz: os livros vendidos e pagos adiantadamente nem sempre puderam ser feitos. Escandalosos processos expuseram essa miséria com muita frequência. O que há, então, de espantoso no fato de o comércio livreiro, assim colocado entre todas as causas de ruína, entre seu próprio charlatanismo, as exigências dos autores, as cobranças dos jornais e, enfim, a contrafação estrangeira tenha sucumbido? Pois nesse momento não há mais edição, a não ser a da universidade, de direito, de medicina, de religião, precisamente porque nesses ramos especiais ela permaneceu quase subtraída aos diversos ataques.

Eu nomeei a contrafação estrangeira, e a nomeei por último porque, com efeito, ela só vem em último lugar em meu pensamento e porque há muitas outras causas mortais antes dela. Tal não parece ser a opinião de muitos interessados, e é quase unicamente à contrafação estrangeira que autores e editores atribuíram a culpa na última crise. Eu creio, entretanto, que eles mesmos foram os primeiros a favorecer a contrafação belga, que se funda antes de tudo sobre a venda de volumes grossos de matéria e baratos. ${ }^{18}$ Mas, sem querer menosprezar o prejuízo imenso que traz a contrafação externa, aí nada se pode fazer diretamente: seria preciso uma intervenção do governo, uma negociação internacional. Fazem bem em provocar e chamar a atenção do poder sobre este ponto; o poder fingiu se ocupar disso, como doravante sempre fará daquilo que lhe for denunciado com ruído e expectativa de um grande acordo de interesses: mas tudo se limitou a demonstrações. Que ele seja incitado, todavia, que seja exortado e edificado a 
esse respeito, se há meio: nada melhor e, com constância e uns cinquenta anos de lutas, nossos Wilberforce ${ }^{19}$, que compararam a contrafação estrangeira ao tráfico dos negros, poderão destruí-la. Mas, ainda outro golpe, não há nada aí sobre o que se possa agir de imediato, e isso é tão verdadeiro que a sociedade fundada recentemente por ocasião desse debate, a Sociedade dos Homens de Letras ${ }^{20}$, após ter estabelecido o princípio geral, teve de aplicar sua atividade a detalhes mais internos.

A ideia primeira dessa sociedade é devida a um escritor de engenho, M. Desnoyers, que soube conservar, na combinação mais ativa, intenções retas e hábitos de caráter elevados. No que me permitirei dizer da associação nascente, eu me ocuparei menos de seu objeto positivo e financeiro do que das consequências literárias prováveis e de certos abusos (eles se insinuam em toda parte, sobretudo nas corporações) que já se poderiam entrever. Seguramente não há nada mais legítimo do que homens de letras se associando para se entenderem e se esclarecerem sobre seus interesses materiais. Em lugar da contrafação estrangeira, que não se pode atingir, há formas de contrafação no interior, senão para os livros, ao menos para os folhetins: há jornais ladrões que nos citam e nos copiam. Alguns autores obstinados poderiam se sentir pura e simplesmente lisonjeados; os mais aguerridos e severos usariam do direito de repressão, requerendo na justiça a indenização; o mais seguro e mais frutífero é levar, pela transação, esses jornais a pagarem tributo pela reprodução e, de certa maneira, pagar-nos uma assinatura. Em uma palavra, regularizar esse gênero de contrafação no interior, eis um resultado. Como o homem de letras isolado tem pouca força, e muitas vezes pouco conhecimento dessas chicanas, um agente especial e um comitê permanente velarão por ele e defenderão seu interesse. Até aí nada melhor. No entanto, sempre é preciso tomar cuidado para o poder do comitê não alienar demais os direitos do indivíduo. Se, por exemplo, ao tratar com cada membro da sociedade, um editor descobrisse ter negócios com uma sociedade que é de fato mais proprietária de suas obras, sob certos aspectos, do que ele mesmo, isso seria um inconveniente, um entrave, uma verdadeira servidão. Se uma Revista (para precisar ainda mais), que paga por um artigo a um autor, se encontrasse quase imediatamente espoliada desse artigo por algum jornal que pagasse tributo regular de reprodução a esse autor, essa seria uma maneira irônica de sermos logrados: seríamos contrafeitos debaixo dos nossos narizes, com a ajuda daquela que teria sido fundada precisamente contra a contrafação. Mas deixo de lado essas questões, que dizem respeito ao que há de mais sutil no código de comércio; eu não sei até onde a legalidade se acomodará a elas; os tribunais, colocados em posição de se pronunciar em alguns casos, parecem até aqui pouco condescendentes, e os velhos juízes, abrindo grandes olhos, não entendem nada disso. Compreende-se, no entanto, eu o repito, uma sociedade de homens de letras que entram em acordo sobre a melhor maneira de assegurar o maior salário possível para suas vigílias, se a sua força unida se contém nos termos de equidade e não vai jamais até a coação contra os editores: pois não seria preciso cair em nada que lembrasse as coalizões de operários; clamou-se bastante contra a camaraderie ${ }^{21}$, isso já é compagnonage. ${ }^{22}$

Porém, um primeiro resultado moral. Qualquer que seja a legitimidade estrita da questão, não é triste para as letras em geral que a sua condição material e sua preocupação necessitada cheguem a esse nível de organização e de publicidade? Eu sempre imaginei o que se chama propriedade literária como alguma coisa mais simples. Um livro é escrito, 
terminado; a venda é tratada com um editor; cumprimos nossas condições e ele as suas, após o que o livro passa a ser sua propriedade. Se nesse intervalo somos contrafeitos na Bélgica, infelicidade e honra! O editor, ademais, não o deixou de prever totalmente. No lugar de um livro, escrevem-se simples artigos: trata-se com um jornal, cumprem-se mutuamente as condições de cada um. Se somos contrafeitos, copiados por uma folha ladra, é problema do jornal defender o seu bem e recorrer à justiça, se lhe agrada. O autor permanece na ignorância deste detalhe e lava suas mãos do processo. Esta aí, sem dúvida, uma economia política bem elementar e bem mesquinha em matéria de propriedade literária: ela deve causar dó a muitos ilustres; faria levantar os ombros particularmente a mais de um dos nossos doze marechais da França, como os chama o presidente atual da Sociedade dos Homens de Letras em uma carta recentemente publicada; ${ }^{23}$ pois um marechal da França em literatura é um desses homens, como é bem sabido, que oferecem à exploração uma certa superfície comercial. Nossa insignificante e frugal teoria da propriedade literária tem somente uma vantagem: enquanto ela reinou nas letras, elas não ofuscavam os olhos dos passantes com um luxo de financista, nem tampouco se agrupavam em torno de suas misérias.

Mas a Sociedade dos Homens de Letras parece-nos conter em si outros inconvenientes literários, se não tomar cuidado. Em tais associações, a maioria decide; e o que é a maioria em literatura? A sociedade se compromete (é bem simples) a ajudar seus membros, a procurar colocação para seus trabalhos, a aplainar aos jovens que fazem parte dela a entrada na carreira. Mas onde estão as condições literárias e as garantias de admissão? Todo mundo pode dizer-se um homem de letras: é o título de quem não tem nenhum. Os mais empenhados em se passar por tal não são os mais dignos. A sociedade terá em consideração o mérito real na admissão? Pode considerá-lo? Onde estará a prova de habilidade? Nas compagnonages dos diversos ofícios, só se recebem operários formados e provados; mas, em matéria literária, quem decidirá? Eis, então, uma sociedade que receberá a todos os que se oferecerem como homens de letras, e que os ajudará, e que os organizará em uma força compacta; e em todas as questões, as menores, as menos razoáveis, as menos interessantes ao que toca verdadeiramente às letras, gritarão o mais alto, estejamos certos disso. Os engenhos cultivados que a associação inclui já devem ter refletido sobre isso, e por experiência. O que seria uma sociedade que, abrangendo a quase totalidade dos literatos do momento em todos os graus da escala, se tornaria para eles uma espécie de garantia mútua contra a crítica e em prol do elogio? Eu aponto um perigo distante, mas não sem que haja sinais que o prenunciam. Não se vêem jornais entenderem-se maravilhosamente como aliados sobre este ponto, no meio das injúrias que eles se lançam por outras questões? Le Siècle repetia outro dia a carta de um presidente da sociedade, e a reproduzia cortesmente de La Presse, ajuntando, sem rir, que esta carta levantava graves questões. Eu receio que também o espirituoso Charivari ${ }^{24}$, dessa vez, tenha se esquecido de rir. Politicamente, os jornais se atacam, se injuriam, se afrontam e guerreiam: os folhetins confraternizam. Entre uns e outros, a correspondência se faz por baixo, pelo rés-do-chão, pelos subterrâneos.

Mas o que fazer neste momento? E falar assim não é correr grandes riscos? Pois ainda um dos inconvenientes de tal sociedade, se ela não ficar atenta, seria a intimidação. Quando se crê na própria força, abusa-se dela facilmente. Outro dia, aconteceu a uma 
pessoa de nosso conhecimento, o antigo gerente dessa Revue, ser acusado de algo inusitado: ele teria se queixado, gracejando, de negociar com as duas espécies de gente das mais indisciplinadas do mundo: os atores e os homens de letras. Ainda que fosse em uma conversa irreverente, eu não posso crer que M. Buloz ${ }^{25}$ o tenha dito. De qualquer modo, uma nota se achou inserida em dois ou três jornais, naqueles mesmos que se atacam todas as manhãs em política, mas que se entendem tão cordialmente em literatura, nota que tinha um talhe verdadeiramente oficial, e que relatava que diante da notícia do dito escandaloso, o comitê da associação se dirigira ao trocista mal sucedido para receber sua retratação formal. Tudo isso foi inserido sem riso. Então talvez não se possa mais dizer que os homens de letras são indisciplinados, mas sim disciplinados demais, e que a coalizão nesse sentido teria estranhas consequências. Talvez a essa hora haja pessoas que se acreditam os representantes únicos e jurados da literatura francesa, prontos a vos pedir contas das boas ou más palavras, e a vos intimar para comparecer diante deles para a maior dignidade da ordem. Seria uma liberdade a mais que teríamos conquistado, e semelhante a muitas outras, neste século de liberdade: o satírico Boileau e o retratista La Bruyère teriam tido uma condição melhor no seu tempo. De resto, nós falamos à vontade dessa Sociedade dos Homens de Letras, uma vez que, sendo-nos perfeitamente desconhecido um grande número deles, pelo menos uma porção suficiente nos parece oferecer, pelos nomes, toda espécie de garantias. Estamos persuadidos de que, no fundo, uma parte dos membros é da nossa opinião, e que eles saberão, se necessário, resistir às tentativas de invasão imoderada. Se for preciso alguma audácia para isso, eles a terão. Como não estaríamos persuadidos, quando, para citar um exemplo ilustre, descobrimos que o membro que primeiro presidiu a sociedade foi M. Villemain? ${ }^{26}$ Eu não posso deixar de pensar que o talentoso acadêmico só aceitara esse cargo para ter ocasião, com esse bom gosto que não o abandona jamais e essa coragem de espírito da qual ele deu tantas provas em todas as circunstâncias decisivas, de recordar e de sustentar diante dessa democracia literária os verdadeiros princípios da independência e do gosto. É uma pena que outras funções supremas o tenham arrebatado antes que ele pudesse exprimir o que em sua boca teria uma autoridade encantadora. Mas enquanto essa espécie de coragem não faltar aos homens de talento altamente colocados, haverá recurso contra o mal.

M. de Balzac, que foi nomeado por unanimidade presidente, em substituição de M. Villemain, talvez contribua para o mesmo resultado por meios contrários. Homem de imaginação e de fantasia, ele a leva muito facilmente a assuntos que lhe são pouco suscetíveis, e provoca, sem imaginar, consequências fabulosas, cuja ilusão cada olho pode corrigir por si só. Sua carta sobre a propriedade literária, que já indicamos, é feita desse gênero de excesso para recolocar as coisas na perspectiva verdadeira: ela não se dirige a nada menos que a propor ao governo a compra das obras dos dez ou doze marechais da França, a começar por aquelas do próprio autor, que se avalia em dois milhões, se compreendi bem. Vós imaginais o governo indenizando o autor da Physiologie du Mariage a fim de melhor divulgá-la, e vendendo os Contes drolatiques como se vende papel timbrado? ${ }^{27}$ Consequências tão divertidas são muito apropriadas para chamar à razão o demônio da propriedade literária, do qual M. de Balzac talvez não tenha desejado senão zombar de maneira agradável. 
Não; por mais que aumente, a cada crise, sua esperança e sua audácia, a literatura industrial não triunfará; ela não organizará nada de grande nem de fecundo para as letras, porque não é nela que está a inspiração. De alguns anos a esta parte, ela já encalhou magnificamente em duas ou três circunstâncias notáveis. Ela tinha reunido nomes e penas célebres sem uma verdadeira ligação; ela os comprometeu, desacreditou-os individualmente, sem tirar disso nada de coletivo ou de poderoso. Já a vimos em ação nessa empresa gigantesca que se intitulava a Europa Literária, outra vez na Crônica de Paris renovada, outra vez e mais recentemente na imprensa de quarenta francos. No teatro, ela teve ao seu dispor o palco do Renascença: o que ela fez? Graças às rivalidades que logo surgiram, às defecções, às exigências, esse instrumento desencaminhado se refugia na música e se salva, como pode, por traduções de ópera italiana. O drama industrial teve, em outros momentos, ainda outros teatros, o Porte Saint-Martin, o Odeon, o próprio Français, que, para não experimentar as condições ruinosas, logo tiveram que afastá-lo ou só se abrir a ele com precauções. Em uma palavra, essa literatura, que lamentamos ter chamado industrial tantas vezes, quando conhecemos os nomes que nela se misturam, teve o desejo e os instrumentos de inovação, os capitais e os talentos, e sempre desperdiçou tudo: a ideia moral estava ausente, por menor que fosse; a cupidez egoísta de cada um trazia logo a ruína a todos.

No entanto, a cada tentativa retomada, para todos aqueles que ainda amam profundamente as letras, é o momento de vigiar. Nos nossos dias, os baixios se elevam sem cessar, e tornam-se rapidamente o nível comum, enquanto o resto desmorona ou se rebaixa. O mal, sem dúvida, não data de hoje; mas tudo já está no limite, e hoje o ultrapassamos. Os recursos são grandes, mas se não os reunimos eles facilmente voltam-se em sentido contrário. Entrai nas bibliotecas: que competição ardente! Quantos jovens estudantes, e em uma boa direção, parece! Mas quão pouco é preciso para fazer esses nobres esforços se desviarem e abortarem! É então urgente que todos os homens honestos se mantenham firmes, primeiro, cada um em sua própria dignidade (sempre é possível), e unidos entre eles por conveniências fiéis e por uma inteligência simpática, tanto quanto puderem e qualquer que seja o ponto de partida. É o caso, sobretudo, de reencontrar a coragem de espírito e saber desafiar. Que essa literatura industrial exista, mas que ela volte a correr em seu leito, aprofundando-o devagar: muito naturalmente, ele só tende a crescer. Para concluir: duas literaturas coexistem em uma proporção bem desigual e coexistirão cada vez mais, misturadas entre si como o bem e o mal neste mundo, confundidas até o dia do juízo: tratemos de adiantar e amadurecer esse juízo, desembaraçando a boa e limitando a outra com firmeza.

\section{Notas}

\footnotetext{
${ }^{1}$ Artigo publicado na Revue des Deux Mondes, t. 19, 1 de setembro de 1839, p. 675-691. Tradução: Jefferson Cano. Salvo quando indicado tratar-se de nota do autor, todas as notas explicativas acrescidas ao texto são do tradutor. ${ }^{2}$ Charles Augustin Sainte-Beuve (1804-1869), literato e crítico francês muito respeitado no século XIX. Muito ativo na imprensa, colaborou com o Globe, o National, a Revue de Paris, a Revue des Deux Mondes, o Constitutionnel e o Moniteur. À época da publicação desse artigo, já publicara três volumes de poesias - Poesies de Joseph Delorme (1829), Consolations (1830) e Pensées d'Août(1837) -, além do romance Volupté (1832) e da coletânea de estudos
} 
críticos Portraits littéraires, publicados em oito volumes entre 1832 e 1839. Sainte-Beuve foi muito próximo da geração romântica sua contemporânea, notadamente de figuras como Victor Hugo, Alfred de Vigny e do grupo conhecido como cenáculo.

3 "Rari nantes in gurgite vasto", ou "poucos que nadam no vasto oceano" é um verso da Eneida, de Virgílio, canto I, 118. A expressão, comum no século XIX, refere-se a poucas exceções a uma situação.

4 "Paupertas impulit audax ut versus facerem", ou "A pobreza audaz me impeliu a fazer versos" encontra-se nas Epistolas de Horácio, livro II, Epístola II, v. 51-52.

${ }^{5}$ Esses versos encontram-se no canto IV da Art Poétique (1674), de Nicolas Boileau-Despreaux. Inserem-se na seguinte estrofe (v. 125-132): "Trabalhai pela glória, e que um sórdido ganho / Jamais seja o objeto de um ilustre escritor. / Eu sei que um nobre espírito pode, sem vergonha e sem crime, / tirar de seu trabalho um tributo legítimo; / mas não posso suportar esses autores renomados, / Que, desgostosos da glória e de dinheiro esfomeados, / Colocam seu Apolo no penhor de um livreiro / E fazem de uma arte divina um ofício mercenário."

${ }^{6}$ John Law (1671-1729), banqueiro escocês e controlador geral das finanças da França. Recebendo um privilégio para a criação de um banco que açambarcou todas as finanças públicas em 1716, foi responsável por uma bolha especulativa que o levou à bancarrota em 1720, quando teve que fugir da França.

${ }^{7}$ Doença neurológica, também chamada coreia, caracterizada por movimentos involuntários dos membros.

${ }^{8}$ Nota do autor: "Queira o rei não recusar // ou dar, como lhe aprouver, // a Marot cem escudos oportunos, // e ele promete que para guardá-los // não os coserá em seu gibão..." Aconselho que se releiam as encantadoras décimas ao Rei de Navarra: "Meu segundo Rei, eu tenho uma jumenta," etc.; e à Rainha de Navarra: "Meus credores, que não se importam com décimas," etc. Na epístola ao Rei por ter sido roubado, ele esgota todos os rodeios e todas as gentilezas do pedido; não se parece com tantos insaciáveis, diz ele, e não quer pedir mais nada: "Mas eu começo a me envergonhar / / Não quero mais prender-me a vossas dádivas; / / Não digo que, se nada me emprestais, // Eu não o pegue [...] // E sabeis, Senhor, como eu pago? [...] // Eu vos farei uma bela promissória // Para ser paga (é claro, sem usura) // Quando se vir contente todo o mundo; // Ou, se quereis, será para pagar-se // Quando vosso renome e glória terminarem. [...] // Notai, então, se desejais // Nada emprestar: muito me agradaríeis; / Porque ademais eu construí em Clément // onde fiz uma grande despesa, // E em Marot que é um pouco mais longe: / Tudo cairá, não havendo cuidado." Em matéria de fanfarronice, esta última, pela esperteza, não vale mais que outras? Quanto ao fundo do pedido, é o mesmo entre nós; mas como mudou o tom! "Certamente, se a França exerce uma preponderância tão incontestável e tão transcendente na Europa, isso se deve, sobretudo, a dez ou doze homens eminentes, homens de arte, de inteligência, de poesia e de coração, [...] entre os quais me encontro." Eis o novo começo de toda demanda: é ao som da trompa que se entoa daqui por diante sua petição; eu gostava mais da flauta de Marot.

${ }^{9}$ Jules Gabriel Janin estreou na imprensa em 1825, no jornal satírico Figaro, passando, após a revolução de julho de 1830, a assumir parte do folhetim do Journal des Débats, encarregado de resenhar os pequenos teatros.

${ }^{10}$ Jean-Baptiste-Silvere Gaye, visconde de Martignac (1776-1832), nomeado Ministro do Interior em 1828, promoveu algumas reformas liberalizantes, como a lei de 18 de julho daquele ano, que eliminou a censura prévia dos jornais, reduziu a caução exigida para a sua criação, isentando dela as publicações científicas e literárias, e garantiu a todo cidadão francês o direito de fundar um jornal. Em julho de 1830, uma tentativa de revogar essa legislação por uma ordenação de Carlos X foi abortada pela revolução que o depôs.

${ }^{11} \mathrm{O}$ termo filete designa qualquer linha impressa que separa colunas ou seções em uma página de jornal Aqui se refere à linha horizontal que separava a parte inferior da página, na qual se publicava o folhetim.

${ }^{12}$ Nota do autor: Para aqueles que o ignoram, diremos que o reclame é a pequena nota introduzida quase no fim, no interior do jornal, geralmente pago pelo livreiro, inserida no mesmo dia que o anúncio ou no dia seguinte, dando em duas palavras um pequeno julgamento lisonjeiro que prepara e antecipa o do artigo.

${ }^{13} \mathrm{~A}$ imprensa de quarenta francos é um fenômeno editorial surgido em 1836, com a criação dos jornais La Presse e Le Siècle. Naquele momento, os jornais de grande formato tinham como padrão uma assinatura anual por oitenta francos. Émile de Girardin imaginou criar um jornal de grande formato e barato, cobrindo a diferença dos custos por meio de anúncios publicados na quarta página. A ideia seduziu também a Armand Dutacq, que se juntou a Girardin na empreitada, até que desavenças quanto à escolha do redator-chefe os separou. Girardin fundou La Presse e Dutacq fundou Le Siècle, ambos em 1836. 
${ }^{14}$ Armand Carrel (1800-1836) iniciou sua colaboração na imprensa no Globe e no Constitutionnel, fundando, em janeiro de 1830, o National, jornal de oposição ao regime de Carlos X, que cairia em julho daquele ano. Sob o novo regime, Carrel logo passaria à oposição, tornando-se republicano em 1832. Em 1836, em meio à polêmica que se seguiu à criação da "imprensa de quarenta francos", Carrel desafiou Émile de Girardin para um duelo com pistolas, do qual sairia gravemente ferido, morrendo dois dias depois.

${ }^{15} \mathrm{~A}$ expressão equivale a uma denúncia contra quem age em causa própria, em defesa de seus próprios interesses. Trata-se de uma referência à peça L'amour médecin, de Molière. Na primeira cena do primeiro ato, Sganarelle se aconselha com seus amigos sobre como curar a melancolia de sua filha. Monsieur Josse, então, sugere que ele the compre "uma bela guarnição de diamantes, ou de rubis, ou de esmeraldas", ao que Sganarelle responde: "Sois ourives, M. Josse, e vosso conselho lembra um homem que deseja desfazer-se de sua mercadoria".

${ }^{16}$ Fundado em agosto de 1789 para acompanhar os debates da Assembleia revolucionária, o Journal des Débats tornou-se, a partir de 1799, um jornal político e literário. Foi então que ele lançou o folhetim, reunindo nesse espaço efemérides políticas e literárias, críticas teatrais, comentários sobre obras publicadas e variedades. Em julho de 1830, o Journal des Débats não se juntou aos demais no protesto contra a ordenação de Carlos X que revogava a liberdade de imprensa.

${ }^{17}$ Segunda parte de Ilusões Perdidas, publicada em 1835.

${ }^{18}$ Nota do autor: O sucesso da pequena Biblioteca do editor Charpentier prova que bons livros bem recheados e pouco caros teriam boas chances: e eles ainda não foram sempre escrupulosos nas escolhas.

${ }^{19}$ William Wilberforce (1759-1833). Líder do movimento abolicionista inglês, ativo no Parlamento, tanto na campanha pela abolição do tráfico negreiro, proibido pela Inglaterra em 1807, quanto pela abolição da escravidão, promulgada no Império Britânico em 1833, poucos dias antes de sua morte.

${ }^{20}$ A exemplo da Societé des auteurs e compositeurs dramatiques, que fora fundada em 1829 e reorganizada em 1837, a Societé des Gens de Lettres foi fundada em 1838 por Louis Desnoyers e tinha por objetivo proteger a propriedade literária substituindo o autor isolado pela ação coletiva na defesa de seus interesses. Era considerada também uma sociedade de socorro mútuo.

${ }^{21}$ Em um sentido pejorativo, designava a união de pessoas, particularmente escritores ou artistas, para se defenderem e se promoverem mutuamente. Em 1829, a Revue de Paris publicou um artigo de Henri de Latouche, redator-chefe do Figaro, intitulado "Camaraderie Litteraire", que atacava a geração romântica que se reunia no chamado "cenáculo" e inclusive aludia, sem o nomear, ao Joseph Delorme de Sainte-Beuve, publicado naquele ano. Em 1837, o tema foi também encenado em La camaraderie ou la courte échelle, de Scribe.

${ }^{22}$ Compagnonages eram associações de trabalhadores de um mesmo ofício, que atingiram alto nível de organização no século XVIII e foram proibidas pela Revolução Francesa. O mesmo ano de 1839 veria a publicação do Livre du compagonnage, de autoria do marceneiro Agricol Perdiguier, que chamaria a atenção de autores como Georges Sand para o tema, ao qual dedicou seu romance Le Compagnon du Tour de France, publicado no ano seguinte.

${ }^{23}$ Nota do autor: Ver a Presse e o Siècle de 18 e 19 de agosto.

${ }^{24}$ Jornal satírico fundado em 1832 por Charles Philipon, tendo por redator-chefe Louis Desnoyers. Philipon e Daumier celebrizaram-se como caricaturistas nesse jornal. Após entrar em crise financeira a partir de 1835, Le Charivari foi comprado por Armand Dutacq, proprietário do Siècle.

${ }^{25}$ François Buloz era o redator-chefe da Revue des Deux Mondes desde 1831. Até então uma publicação irregular, Buloz foi o responsável pela sua consolidação e sucesso, atraindo os autores mais renomados do momento. Em 1834 comprou também a Revue de Paris, de perfil mais dedicado às letras e artes, a qual, no entanto, logo deixaria de circular. Em 1838, foi nomeado comissário do rei junto à Comédie Française, no que foi muito criticado por ser considerado estranho ao meio teatral. Era célebre por seu mau humor e conhecido como o "autocrata da rua Saint Benoit", o que talvez explique a incredulidade de Sainte-Beuve quanto à suposta irreverência.

${ }^{26}$ Abel-François Villemain (1790-1870), professor da Sorbonne, onde ocupou a cátedra de eloquência francesa entre 1816 e 1826, tornou-se, após a revolução de 1830, membro do Conselho Superior de Instrução Pública e, desde maio de 1839, era o ministro da Instrução Pública.

${ }^{27}$ Physiologie du Mariage fora publicado em 1828 e Les Cent Contes Drolatiquesjá tivera três volumes publicados, em 1832, 1833 e 1837. 
